IRA-International Journal of Education \& Multidisciplinary Studies ISSN 2455-2526; Vol.06, Issue 03 (2017)

Pg. no. 280-290

Institute of Research Advances

https://research-advances.org/index.php/IJEMS

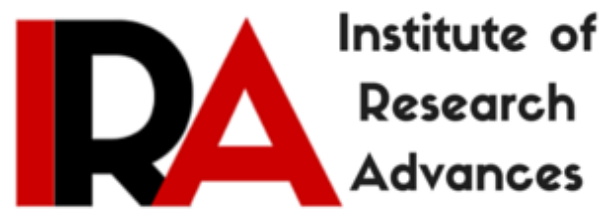

\title{
Teaching the Arithmetic Sequence through Guided Discovery Learning: A Pedagogical Experiment in Viet Nam
}

\author{
Nguyen Van Hong (Ph.D.) ${ }^{1}$ \\ Can Tho Department Education and Training Can Tho City, Vietnam. \\ Nguyen Thi Thuy An (M.sc.) ${ }^{2}$ \\ Tay Do University, Can Tho City, Vietnam. \\ Le Viet Minh Triet (M.sc.) ${ }^{3 \#}$ \\ Pacific College, Can Tho City, Vietnam.
}

\# corresponding author

Type of Review: Peer Reviewed.

DOI: http://dx.doi.org/10.21013/jems.v6.n3.p9

How to cite this paper:

Hong, N., Thuy An, N., \& Triet, L. (2017). Teaching the Arithmetic Sequence through Guided Discovery

Learning: A Pedagogical Experiment in Viet Nam. IRA International Journal of Education and Multidisciplinary Studies (ISSN 2455-2526), 6(3), 280-290. doi:http://dx.doi.org/10.21013/jems.v6.n3.p9

(C) Institute of Research Advances

\section{(cc) BY-NC}

This work is licensed under a Creative Commons Attribution-Non Commercial 4.0 International License subject to proper citation to the publication source of the work.

Disclaimer: The scholarly papers as reviewed and published by the Institute of Research Advances (IRA) are the views and opinions of their respective authors and are not the views or opinions of the IRA. The IRA disclaims of any harm or loss caused due to the published content to any party. 


\begin{abstract}
"Let the student learn by discovery" has become the slogan of our country for recent years. Learning by discovery that has used by Vietnamese teacher is a term has appeared in Viet Nam in the past few years. This study proposes Guided Discovery learning to teach arithmetic sequence topic in Viet Nam high school. It is hypothesized that student. Student's outcomes of teaching arithmetic sequence topic with Guided Discovery Learning are not greater than the ones of teaching this subject with the traditional method of instruction and students' achievements after experiment are not better than students' achievements before the experiment. Two eleven -classes were involved in the trial to investigate the effectiveness of Guided Discovery Learning,. The result suggests that students have better concept retention.
\end{abstract}

Keywords: Guided Discovery Learning, discovery learning, the arithmetic sequence, Pure discovery,

\title{
Introduction
}

Guided discovery learning has been variously defined. Furthermore, it is common, assumed that discovery learning allows for errorful learning, that it is guided to some extent, and that is the outcome of inductive methods of instruction. It demonstrates the ability to meet the requirements innovation of teaching methods that is based on the learner-oriented perspective, helping students self-seek and discover new knowledge on previous experience and his life experiences. In Viet Nam, Guided Discovery Learning is an active method teaching which not only was studied by many researchers but also applied by teachers In recent years (Nguyen Phu Loc, 2010 [4]);Le Vo Binh, 2007 [1]).

This paper presents an experiment was to confirm that teaching the arithmetic sequence topic by guided discovery learning is more efficient than the traditional method in Viet Nam.

\section{Discovery learning}

Discovery learning is an action-based learning approach that stresses experimentation and hypothesis testing. It is a type of learning where learners construct their knowledge by experimenting with a domain and inferring rules from the results of these experiments (van Joolingen, 1999 [10]). Discovery learning is based on the assumption that education is a process, not a set of facts.

It occurs when individuals have to use the process of thought to find out the meaningfulness of something themselves (Bruner, 1961 [2]). He gives four reasons for using discovery learning as follow: (i) To make an impulse of thought, (ii) to develop inner motivation than external motivation, (iii) to learn the way of discovery and (iv) to develop thought (Bruner, 1961 [2]).

Bruner believed that the process of discovery contributes significantly to the intellectual development and that the heuristics of discovery can only be learned through the exercise of problem-solving. $\mathrm{He}$ proposed discovery learning as a pedagogic strategy with such important human implications that it must have applied in schools.

Several types of discovery learning are recognized as given below (Kersh, 1962A, 1964 [5-7]; Kersh and Wittrock, 1962 [8]; Kittell, 1957 [9]; Wittrock, 1963 [11]):

Pure discovery: techniques involving no direct assistance, other than encouragement, by a teacher.

Guided discovery: techniques involving minimal to moderate aid by a teacher.

Expositional learning: highly directed learning involving maximal help by a teacher and usually little or no actual discovery by the student. 
Kersh and Wittrock (1962) [11] stated that guided discovery is the most motivating of the three types. The reason appears to be that the reinforcement given by a teacher in the form of encouragement and support (even if the pupil does not discover the correct answer) motivates the child to continue working and he, in turn, becomes more motivated.

In Guided Discovery Learning, the teacher devises a series of statements or questions that guide the students, step by step, making a series of exploring that leads to a single predetermined goal. In another word, the teacher initiates a stimulus, and the learner reacts by engaging inactive inquiry thereby discovering the appropriate response.

\section{The pedagogical experiment on teaching the arithmetic sequence}

\section{Objectives of the pedagogical experiment}

Investigate to find out the effectiveness and to use guided discovery learning methods currently in high school.

\section{Hypothesis}

H01: There is no significant difference between the learning outcome of students who are taught abuse Guided Discovery Learning and the students in the control group.

H02: There is no significant difference the achievements after the experiment and the ones of students before the test.

\section{Selection of Content}

Theory of the arithmetic sequence which consists of the definition of the arithmetic progressions and the formula $u_{n}=u_{1}+(n-1) d$ is the topic for the trial treatment was selected from the Algebra and Analysis 11 that was used for high mathematics education in Vietnam.

\section{Sample for the study}

The pedagogical experiment conducted experiment according to the model "Two groups - posttest," wherein math ability of student's two groups (two classes) selected is equivalent. It has been studied at the Pacific College (primary, secondary and high school), Can Tho city. The design of the study is as Table 1 follow:

\section{Table 1: The experimental model}

\begin{tabular}{|l|c|c|c|}
\hline Experimental class (EC) & O1 & $\mathrm{X}$ & $\mathrm{O} 2$ \\
\hline Control class (CL) & O3 & -- & O4 \\
\hline
\end{tabular}

Where

$\mathrm{O} 1, \mathrm{O} 3=$ Measurement $($ pre-test $)$

$\mathrm{O} 2, \mathrm{O} 4=$ Measurement (post test)

$X=$ Treatment (Guided Discovery Learning)

--- = No Treatment 
A summary of the design is represented in Table 2

Table 2: Design of the Study

\begin{tabular}{|l|l|l|}
\hline \multicolumn{1}{|c|}{ Phase } & \multicolumn{1}{c|}{ Control group } & \multicolumn{1}{c|}{ Experimental Group } \\
\hline $\begin{array}{l}\text { 1. Pre-test } \\
\text { (90 minuses) }\end{array}$ & $\begin{array}{l}\text { the first semi-semester } \\
\text { Achievement Test }\end{array}$ & $\begin{array}{l}\text { the first semi-semester } \\
\text { Achievement Test }\end{array}$ \\
\hline $\begin{array}{l}\text { 2.Experimental } \\
\text { interventions } \\
\text { (90 minuses) }\end{array}$ & $\begin{array}{l}\text { Lecture method and } \\
\text { lecture-demonstration } \\
\text { method }\end{array}$ & $\begin{array}{l}\text { Guided Discovery } \\
\text { Learning }\end{array}$ \\
\hline $\begin{array}{l}3 . \text { Post Test } \\
\text { (90 minuses) }\end{array}$ & Achievement Test & Achievement Test \\
\hline Class & 11.2 & 11.1 \\
\hline $\begin{array}{l}\text { Total number of students } \\
\text { (N) }\end{array}$ & \multicolumn{2}{|c|}{22} \\
\hline
\end{tabular}

The experiment was carried out in the final of the first semester of the academic year2016-2017. Before the test was conducted, mathematics learning outcomes of students of experimental class and control class were equivalent. Particularly, after finishing the first semi-semester of the academic year 2016 - 2017 (before experiment) average marks of the mathematics of students in experiment class and control class were 5.318182 and 5.409091, respectively; and according to data analysis of Excel 2013.

Table 3: Comparing the mathematics ability of experiment and control class before the pedagogical experiment

\begin{tabular}{|lll|}
\hline t-Test: Paired Two Sample for Means & & \\
\hline Mean & $\begin{array}{l}\text { Experimental } \\
\text { class }\end{array}$ & $\begin{array}{l}\text { Control } \\
\text { class }\end{array}$ \\
Variance & 5.318182 & 5.409091 \\
Observations & 2.512987 & 1.205628 \\
Pearson Correlation & 22 & 22 \\
Hypothesized Mean Difference & 0.113161 & \\
Df & 0 & \\
t Stat & 21 & \\
\end{tabular}




\begin{tabular}{lc}
$\mathrm{P}(\mathrm{T}<=\mathrm{t})$ one-tail & 0.408682 \\
$\mathrm{t}$ Critical one-tail & 1.720743 \\
$\mathrm{P}(\mathrm{T}<=\mathrm{t})$ two-tail & 0.817363 \\
$\mathrm{t}$ Critical two-tail & 2.079614 \\
\hline
\end{tabular}

Table3 indicated that $\mathrm{t}$-value is- 0.23385 and $\mathrm{P}-\mathrm{value}$ is 2.079614 . The result is not significant at $\mathrm{p} \leq 0.05$. Therefore, means is not different and so, mathematics learning outcomes of students in preparatory classes and control class are not different before the experiment was carried out.

Teaching methods applied in experimental class: We used "Guided discovery learning" for teaching the arithmetic sequence. In teaching process, teacher operated to guide his students to discover arithmetic sequence knowledge. Based on the models for teaching mathematical concepts by guide discovery which was outlined by Nguyen Phu Loc (2010), we designed the lesson as Table $\mathbf{4}$ and

Table 5.

Table 4: The lesson for teaching the definition of the arithmetic progressions

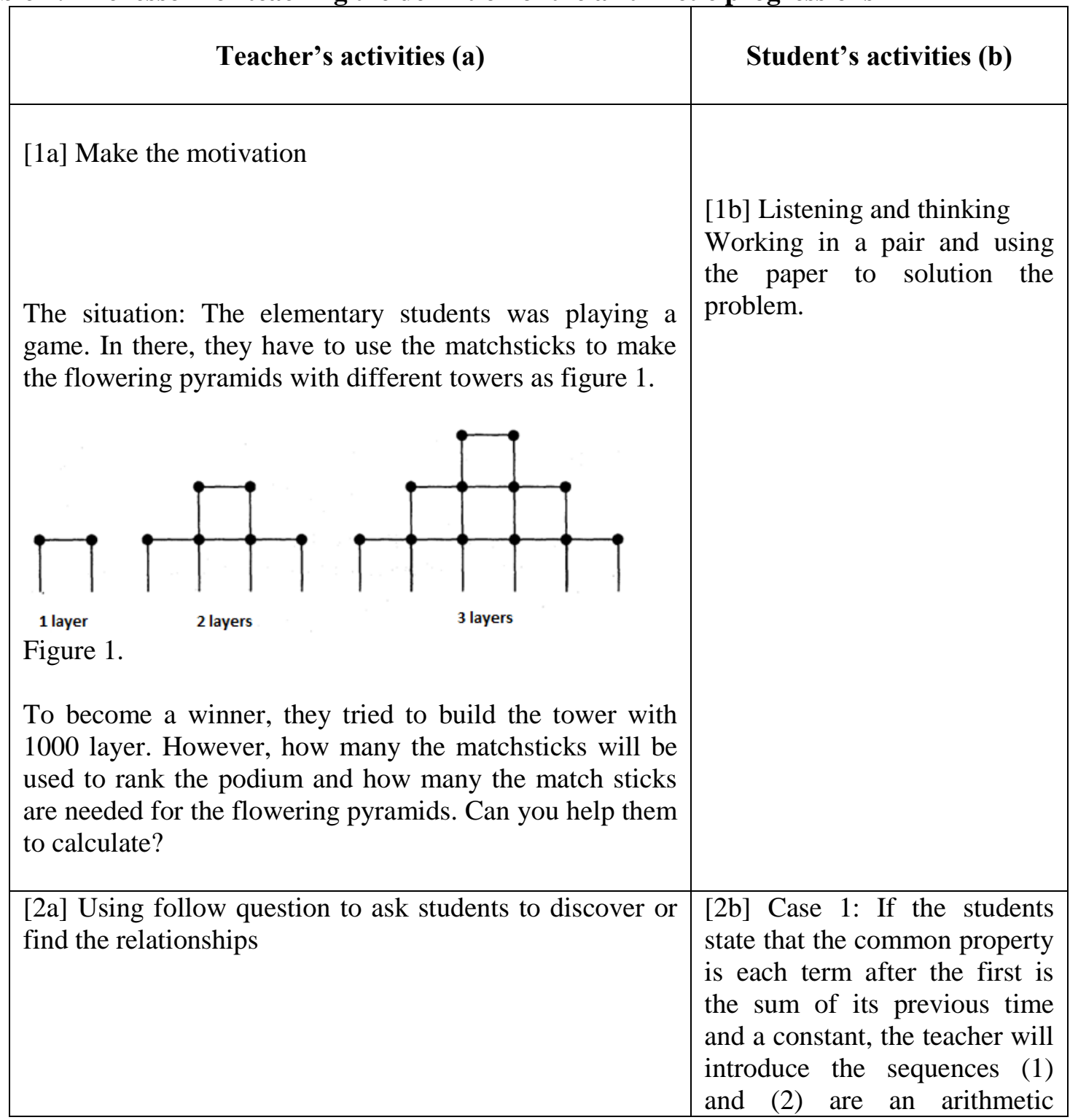




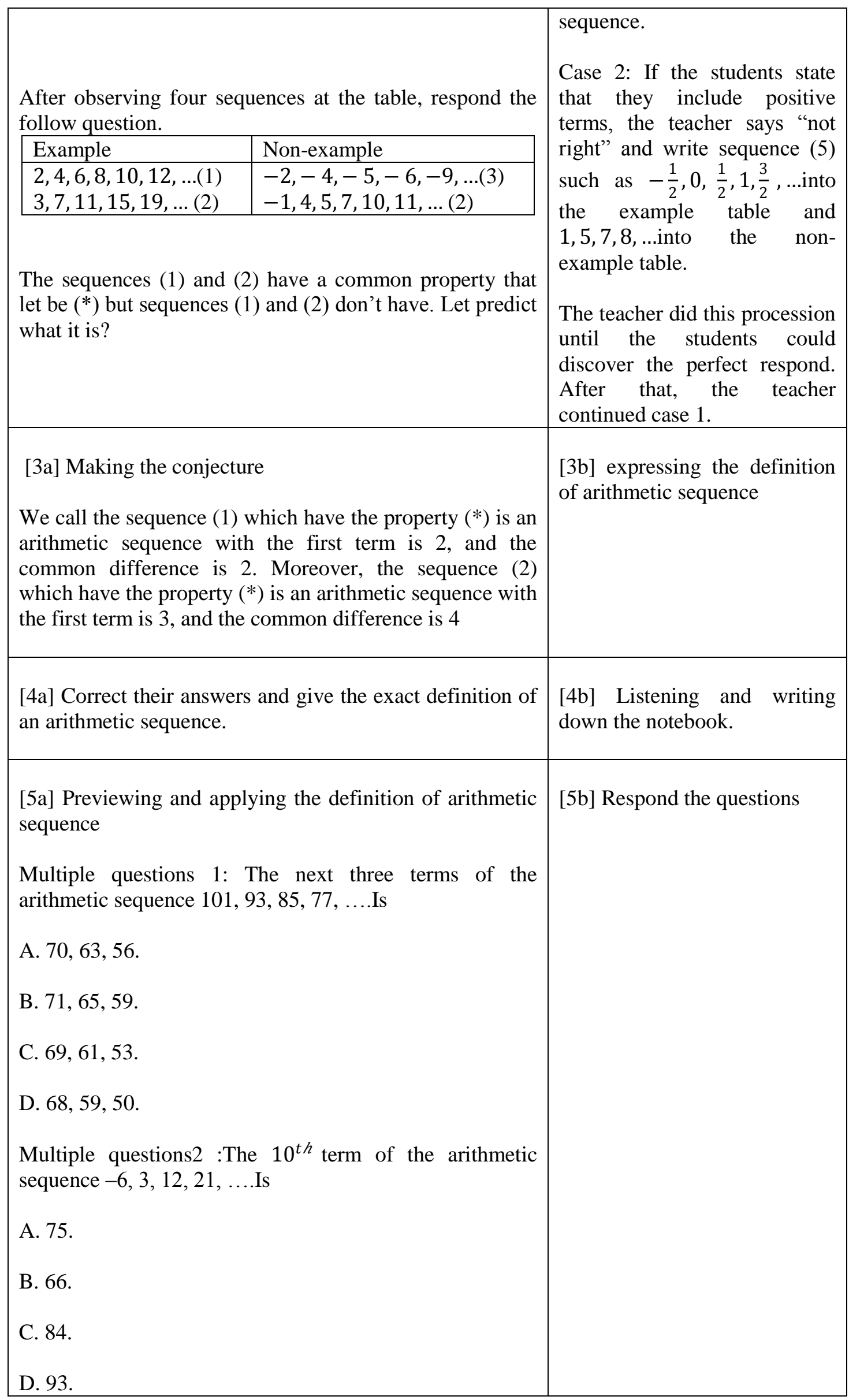


Question 3: Find the $1000^{\text {th }}$ term of the arithmetic sequence $-6,3,12,21, \ldots$

Question 4: Which the following sequences are an arithmetic one? Calculate its first term and common difference.
a) $2,5,9,14,20, \ldots$
b) $25,23,31,19, \ldots$
c) $\frac{1}{3}, \frac{2}{3}, 1, \frac{4}{3}, \frac{5}{3}, \ldots$
d) $u_{n}=4+3 n$

Table 5: The lesson for teaching the general term of the arithmetic progressions

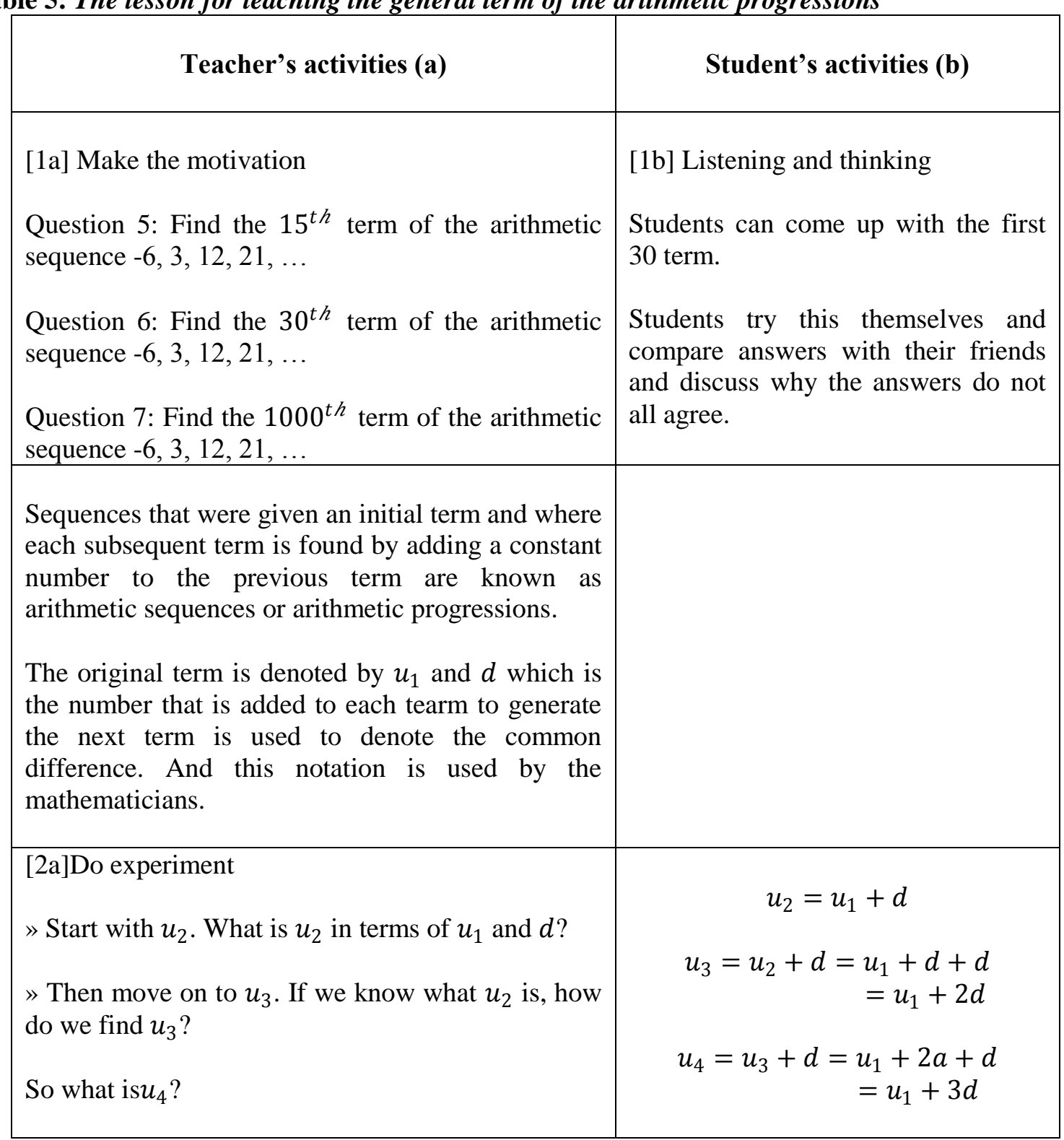




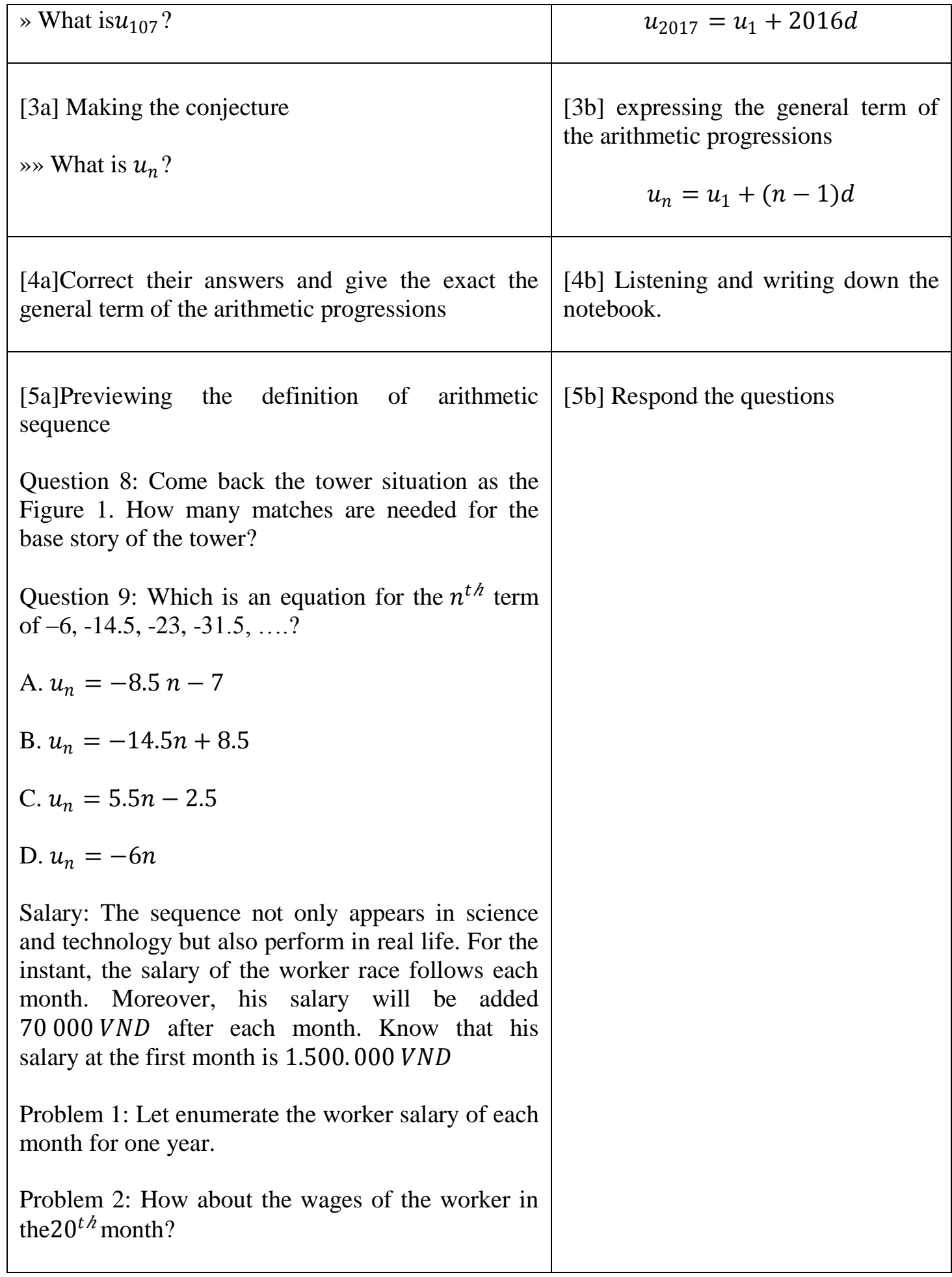

\section{Findings}

\section{Effectiveness of Guided Discovery Learning on the learning outcome}

After finishing the experiment, students of experimental and control classes were required to do the same test consisting of sixteen multiple choice question and three essay exercises. Table 6 presents the results of students. 
Table 6: Test scores of experimental and control classes after the experiment

\begin{tabular}{|l|l|c|c|c|c|c|c|c|c|}
\hline Group & Mark & $0-1,9$ & $2,0-3,4$ & $3,5-4,9$ & $\begin{array}{c}5,0- \\
6,4\end{array}$ & $6,5-7,9$ & $8,0-10$ & $\begin{array}{c}\text { Average } \\
>=5,0\end{array}$ & Sum \\
\hline & $\begin{array}{l}\text { The } \\
\text { number } \\
\text { of } \\
\text { students }\end{array}$ & 0 & 0.0 & 1.0 & 8.0 & 8.0 & 5.0 & 21.0 & 22 \\
\cline { 2 - 11 } & $\begin{array}{l}\text { EC } \\
\text { Rate }\end{array}$ \\
$\begin{array}{l}\text { E }) \\
\text { CL }\end{array}$ & 0 & 0 & 3 & 22 & 22 & 14 & 58 & 61 \\
\hline $\begin{array}{l}\text { The } \\
\text { number } \\
\text { of } \\
\text { students }\end{array}$ & 0 & 2.0 & 4.0 & 8.0 & 6.0 & 2.0 & 16.0 & 22 \\
\cline { 2 - 11 } & $\begin{array}{l}\text { Rate } \\
(\%)\end{array}$ & 0 & 6 & 11 & 22 & 17 & 6 & 44 & 61 \\
\hline
\end{tabular}

It is seen from Table 7 that is a statistically significant difference between the mean score of the experimental group and the control group, as indicated by the t value, tStat $=2.347173, p<0.05$. Hence, the null hypothesis (H01) stating that there is no significant difference between the learning outcome of students who are taught through Guided Discovery Learning and the students in the control group is rejected. That means that there has been a significant increase in the students in the learning outcome of students due to the experimental treatment through Guide Discovery Learning $($ mean $=6.590909)$ as compared to the control group $($ mean $=5.636364)$.

Table 7: Comparing the results of experiment and control class after the Pedagogical Experiment

t-Test: Two-Sample Assuming Unequal Variances

\begin{tabular}{|lll|}
\hline & EC & CL \\
\hline Mean & 6.590909 & 5.636364 \\
Variance & 1.300866 & 2.337662 \\
Hypothesized Mean Difference & 22 & 22 \\
Df & 0 & \\
t Stat & 39 & \\
$\mathrm{P}(\mathrm{T}<=\mathrm{t})$ one-tail & 2.347173 &
\end{tabular}


t Critical one-tail

1.684875

$\mathrm{P}(\mathrm{T}<=\mathrm{t})$ two-tail

0.024087

t Critical two-tail

2.022691

Table 8: t-Test paired two samples for means of class before and after experiment

t-Test: Paired Two Sample for Means

\begin{tabular}{|lll|}
\hline & Pre-test & Post-test \\
\hline Mean & 5.318182 & 6.590909 \\
Variance & 2.512987 & 1.300866 \\
Observations & 22 & 22 \\
Pearson Correlation & 0.628501 & \\
Hypothesized Mean Difference & 0 & \\
Df & 21 & \\
t Stat & -4.8087 & \\
P(T<=t) one-tail & $4.71 \mathrm{E}-05$ & \\
t Critical one-tail & 1.720743 & \\
$\mathrm{P}(\mathrm{T}<=t)$ two-tail & $9.43 \mathrm{E}-05$ & \\
t Critical two-tail & 2.079614 & \\
\hline
\end{tabular}

A comparison of the average of scores of pre and post tests of the experimental group taught through Guide Discovery Learning

Table 8 shows that in the experimental group there was a significant increase in mean scores of science achievement from pre-test $($ mean $=5.318182)$ to posttest $($ mean $=6.590909)$, a positive gain of $123.83 \%$ in learning achievement due to experiment treatment through Guided Discovery Learning. Moreover, the absolute of calculated t-Stat exceeds the critical value $(|4.8087|>2.079614)$ and the p-significant at $\mathrm{p} \leq 0.05(9.43 \mathrm{E}-05<0.05)$. Therefore, the null hypothesis $\mathrm{H} 02$ is excepted, and the achievement of class after the experiment is better than the one of class before the experiment.

\section{Conclusion}

The above example demonstrates that the use of guide discovery was more effective than teaching with the traditional method. In Guided Discovery Learning, the teachers assist students to construct knowledge through inquiry or discovery by actively involving in the knowledge construction process, thus developing the thinking abilities of students. 


\section{References}

1. Bruner, J. (1961). The act of discovery. Harvard Educational Review, 21- 32.

2. Kersh, B.Y. (1962). The motivating effect of learning by directed discovery. Journal of educational psychology, 53, 65-71.

3. Kersh, Bert Y. (1964). Learning by Discovery: What is Learned? The Arith. Teacher,11(4), 226-232.

4. Kersh, Bert Y. (1964). Learning by Discovery: What is Learned? The Arith. Teacher,11(4), 226-232.

5. Kersh, Bert Y., and Merl C. Wittrock. (1962). Learning by Discovery: An Interpretation of Recent Research. The J. of Teacher Ed., 13(4), 461-468.

6. Kitell,J.E. (1957). "An experimental study of the effect of external direction duringlearning on transfer and retention of principles," Journal of Educational Psychology, 48, 391-405.

7. Le Vo Binh (2007). Teaching geometry for the last grades of the secondary school oriented discovery learning. A Dissertation for the Degree of Doctor of Education, Vinh University (Dissertation written in Vietnamese).

8. Nguyen Phu Loc (2010). Teaching mathematical concepts by discovery. Journal of Can Tho University. No 14. 16-21.

9. Tran Van Hao, Vu Tuan, Dao Ngoc Nam, Le Van Tien, Vu Viet Yen (2015). Algebra and Analysis 11. Viet Nam Education Publishing House.

10. Van Joolingen,W.R.(1999).Cognitive tools for discovery learning. International Journal of Artificial Intelligence in Education, (10), 385-397.

11. Wittrock, M. C. (1963). "Verbal Stimuli in Concept Formation: Learning by Discovery."J. Ed. Psych., 54(4), 183-190. 